\title{
Formulasi Lengkap Larutan Pengawet Bunga Potong Anyelir (Dyanthus caryophillus)
}

\author{
Farida Iriani \\ Fakultas Pertanian Universitas Bandung Raya, Jl. Cikutra no. 171 Bandung \\ Korespondensi: gladya_puspasari@yahoo.com
}

\begin{abstract}
Formulation of preservative solution for Carnation (Dyanthus caryophillus)

Preservative solution for cut flower carnation (Dyanthus caryophillus) by using formulated preservative solution that contains sucrose, citric acid, and lysol as the base substances is effective to maintain the quality of carnations cut flower. Growth factor cytokinin or anti ethylene are added to basic preservative solution to examine its effectivity in increasing the quality of cut flower. Experiment was conducted by using Randomized Block Design consisted of five factors with five replications. The result of this experiment showed that by adding cytokinin or silver thyosulphate into the preservative solution, enhance quality of cut flower, as demonstrated by vaselife, the number of microbe colonies, the development of relative 2-days fresh weight, the synthesized of ethylene, and respiration.
\end{abstract}

Key word: Carnation, Climacteric respiration, Cytokinin, Ethylene, Silver thyosulphate.

\begin{abstract}
ABSTRAK
Pemanfaatan larutan pengawet berfomula bahan dasar sukrosa, asam sitrat, dan lisol adalah efektif mempertahankan kualitas bunga potong anyelir. Pemanfaatan larutan pengawet berformula bahan dasar yang ditambahkan senyawa pengatur tumbuh sitokinin atau senyawa anti etilen telah dilakukan dengan tujuan untuk mengkaji keefektifannya dalam meningkatkan kualitas bunga potong itu. Percobaan menggunakan Rancangan Acak Kelompok terdiri atas lima faktor yang diulang tiga kali. Hasil percobaan menunjukkan bahwa penambahan kinetin atau perak tiosulfat ke dalam formula dasar memberi efek yang lebih baik terhadap kualitas bunga potong anyelir dibandingkan dengan perendaman dalam larutan pengawet berformula dasar saja, sebagaimana terukur melalui umur peragaan, jumlah koloni mikroba, perkembangan bobot segar relatif 2-harian, etilen yang disintesis dan respirasi.

Kata kunci: Anyelir, Repirasi klimakterik, Kinetin, Etilen, Perak tiosulfat.
\end{abstract}

\section{PENDAHULUAN}

Konsumen bunga potong menginginkan umur peragaan yang panjang, diameter petal yang lebar, dan warna yang lambat pudar. Bunga potong anyelir (Dianthus caryophillus) adalah salah satu jenis bunga potong dengan permintaan domestik tinggi terutama karena warnanya bervariasi sehingga relatif mudah dipadupadankan dalam suatu rangkaian.

Upaya mempertahankan atau bahkan meningkatkan kualitas bunga potong akan efektif melalui perbaikan pascapanen, antara lain penam- bahan bahan pengawet ke dalam larutan pengawet kimia yang sesuai untuk masing-masing jenis bunga. Larutan pengawet dengan komposisi $51 \mathrm{mg} \mathrm{L}^{-1}$ sukrosa $+254 \mathrm{mg} \mathrm{L}^{-1}$ asam sitrat $+847 \mathrm{mg} \mathrm{L}^{-1}$ lisol cocok untuk bunga potong anyelir kultivar Red Sims (Iriani, 2009). Senyawa kimia tersebut masingmasing berperan sebagai sumber energi, katalis yang dapat menurunkan $\mathrm{pH}$ larutan perendam, dan menurunkan tingkat respirasi sel dari serangan mikroba (Iriani, 2006). Penambahan zat pengatur tumbuh yang mampu menunda senesen maupun senyawa yang mampu menghambat biosintesis etilen 
(disebut anti etilen) juga efektif untuk diformulasikan sebagai bahan pengawet.

Sitokinin adalah zat pengatur tumbuh yang cukup konsisten dalam menunda senesen (Arteca, 1996). Sitokinin dari jenis benziladenin, baik secara tunggal maupun bersama-sama senyawa kompleks perak tiosulfat efektif menunda senesen bunga potong anyelir (Kelly \& Staby, 1982). Pencelupan cepat pada larutan benzilaminopurin $10 \mathrm{mM}$ menunda absisi dan pemudaran bunga potong Greviella kultivar Sylvia (Setyadjit et al., 2004).

Mekanisme kerja senyawa anti etilen dalam menghambat sintesis maupun aksi etilen pada prinsipnya berbeda. Penghambatan sintesis etilen dapat dimulai dari penghambatan aktivitas enzim ACC sintase yang mengubah asam amino ribose adenine (SAM) menjadi asam amino siklopropen-1karboksilat (ACC) (McKeon et al., 1995; Sisler \& Serek, 1999). Ditambahkan oleh Sisler \& Serek (1999) bahwa penghambatan aksi etilen pada saat penerimaan pesan transduksi etilen ke protein penerima adalah efektif dengan mengaplikasikan senyawa kompleks perak tiosulfat.

Berdasarkan acuan di atas maka penelitian ini dilaksanakan untuk mendapatkan formula bahan pengawet yang terdiri atas tiga senyawa dasar (sukrosa, asam sitrat, dan lisol) serta senyawa anti etilen atau zat pengatur tumbuh sitokinin sebagai senyawa pelengkap. Bagaimana efek formulasi senyawa lengkap tersebut terhadap peningkatan kualitas bunga potong anyelir yang diamati melalui beberapa variabel respon merupakan tujuan dari penelitian ini.

\section{BAHAN DAN METODE}

Bahan yang diperlukan untuk pembuatan larutan pengawet adalah senyawa sukrosa komersial (gula pasir), asam sitrat, lisol, zat pengatur tumbuh sitokinin jenis kinetin dan benzilaminopurin (BAP), senyawa anti etilen jenis asam oksiasetat (AOA) dan perak tiosulfat (PTS), akuades, dan air bersih kualitas PDAM.

Percobaan menggunakan Rancangan Acak Kelompok faktor tunggal (Gaspersz, 1991) dengan lima perlakuan dan diulang tiga kali dengan masingmasing perlakuan adalah formula dasar larutan pengawet (51 mg L-1 sukrosa $+254 \mathrm{mg} \mathrm{L}^{-1}$ asam sitrat $+847 \mathrm{mg} \mathrm{L}^{-1}$ lisol) tanpa dan dengan $10 \mathrm{mg} \mathrm{L}^{-1}$ kinetin, $10 \mathrm{mg} \mathrm{L}^{-1}$ benzilaminopurin, $50 \mathrm{mg} \mathrm{L}^{-1}$ AOA, $50 \mathrm{mg} \mathrm{L}^{-1}$ PTS. Bunga potong anyelir kultivar Red Sims sebanyak 75 tangkai dengan tingkat keseragaman yang sama digunakan dalam percobaan ini dengan tangkai bunga lurus, panjang tangkai 30-50 cm, petal tidak cacat dan diameter petal 4-5 $\mathrm{cm}$. Bunga direndam di larutan pengawet selama 15 jam (Iriani, 2006).

Variabel respon yang diamati adalah umur peragaan, populasi mikroba $\left(\mathrm{CFU} \mathrm{g}^{-1}\right)$, perkembangan bobot segar relatif 2-harian (\%), perkembangan serapan air relatif 2-harian $\left(\mathrm{g} \mathrm{g}^{-1}\right)$, respirasi $\left(\mathrm{CO}_{2} \mu \mathrm{L}\right.$ $\left.\mathrm{g}^{-1} \mathrm{jam}^{-1}\right)$, dan etilen yang disintesis $\left(\mathrm{C}_{2} \mathrm{H}_{4} \mu \mathrm{L} \mathrm{g}^{-1} \mathrm{jam}^{-1}\right)$ hingga empat kali pengamatan. Jumlah koloni mikroba dihitung menggunakan metode pengenceran pada medium Nutrient Agar (Atlas \& Bartha, 1995). Jumlah gas $\mathrm{CO}_{2}$ dan $\mathrm{C}_{2} \mathrm{H}_{4}$ yang dikeluarkan bunga anyelir terdeteksi melalui alat GCMS merk Shimadzu type 171-5050 berisi $5 \%$ senyawa fenil metil silikon pada kolom hp-5, panjang gelombang $25 \mathrm{~nm}$ menggunakan gas carrier helium (Horgan, 1995). Sebagai data penunjang diukur $\mathrm{pH}$ larutan pengawet dan suhu ruang rata-rata harian.

Variabel respons umur peragaan dan jumlah koloni mikroba dianalisis dengan sidik ragam Rancangan Acak Kelompok univariat dan dilanjutkan dengan uji Beda Nyata Terkecil (BNT) pada taraf uji 0,05 (Kramer, 1972). Data perkembangan bobot segar relatif (BSR), dan perkembangan serapan air relatif (SAR) diperoleh melalui input data primer, dan dihitung dengan menggunakan rumus berikut (Setyadjit et al., 2004):

$$
\mathrm{BSR}=\frac{\mathrm{Wt}}{\mathrm{Wt}-2}
$$

$\mathrm{W}_{\mathrm{t}} \quad$ = bobot segar bunga potong (g) pada hari ke $3,5,7, \ldots$

$\mathrm{W}_{\mathrm{t}-2}=$ bobot segar bunga potong (g) pada hari ke t-2

$$
\mathrm{SAR}=\frac{\mathrm{St}-2-\mathrm{St}}{\mathrm{Wt}-2}
$$

St = bobot air dalam jambangan (g) pada hari ke $3,5,7, \ldots$

$\mathrm{S}_{\mathrm{t}-2}=$ bobot air dalam jambangan (g) pada hari ke $\mathrm{t}-2$

$\mathrm{W}_{\mathrm{t}-2}=$ bobot segar bunga potong (g) pada hari ke $\mathrm{t}-2$

Jumlah etilen yang disintesis dan respirasi klimaterik serta hubungannya dengan umur peragaan bunga potong, diduga menurut sidik regresi model kuadratik menurut Gasperz (1995). Kurva yang diperoleh diperbandingkan dengan uji keseja- 
jaran dan keberhimpitan menurut Draper \& Smith (1981).

\section{HASIL DAN PEMBAHASAN}

\section{Umur peragaan dan populasi mikroba}

Senyawa kinetin atau PTS yang ditambahkan ke dalam larutan pengawet formula dasar efektif menekan pertumbuhan dan perkembangan bakteri, kecuali Klebsiela pneumoniae dan Klebsiela oxytoca (jenis bakteri teridentifikasi) di dasar tangkai bunga anyelir (Tabel 1).

Tabel 1. Umur peragaan dan jumlah koloni mikroba bunga potong anyelir yang direndam dalam larutan pengawet dengan zat pengatur tumbuh

\begin{tabular}{|c|c|c|}
\hline \multirow{2}{*}{$\begin{array}{c}\text { Zat } \\
\text { pengatur } \\
\text { tumbuh }\end{array}$} & \multicolumn{2}{|c|}{ Variabel respons } \\
\hline & $\begin{array}{c}\text { Umur peragaan } \\
\text { (Hari) }\end{array}$ & $\begin{array}{l}\text { Populasi mikroba } \\
\left(\times 10^{6} \mathrm{CFUg}^{-1}\right)\end{array}$ \\
\hline Kontrol & $7,33 \mathrm{c}$ & 4,411 \\
\hline kinetin & $10,00 \mathrm{e}$ & $4,23 \mathrm{n}$ \\
\hline BAP & $9,00 \mathrm{de}$ & $4,33 \mathrm{~m}$ \\
\hline $\mathrm{AOA}$ & $7,67 \mathrm{~cd}$ & $4,29 \mathrm{~m}$ \\
\hline PTS & 9,33 e & $4,23 \mathrm{n}$ \\
\hline
\end{tabular}

Keterangan: Nilai yang diikuti dengan huruf sama, dalam satu kolom, tidak berbeda nyata menurut Uji Beda Nyata Terkecil pada $\operatorname{taraf} 5 \%$

Penambahan sitokinin atau anti etilen (kecuali AOA) ke dalam larutan pengawet mampu memperpanjang umur peragaan dibandingkan dengan kontrol. Tidak ada perbedaan peningkatan umur peragaan bunga anyelir di dalam larutan pengawet yang ditambah kinetin, BAP maupun PTS. Perbedaan bermakna tampak pada jumlah koloni mikroba.

Populasi mikroba di dasar batang bunga yang direndam dalam larutan ditambah kinetin atau PTS lebih rendah daripada dalam formula dasar dengan BAP atau AOA sehingga umur peragaan anyelir lebih panjang. Hasil percobaan ini sejalan dengan penelitian Reid et al. (1980), bahwa aplikasi senyawa PTS yang dikombinasikan dengan senyawa kimia lain memberi efek lebih baik terhadap perpanjangan umur peragaan anyelir tipe spray kultivar Barbi dibandingkan dengan tanpa PTS. Menurut Sisler \& Serek (1999), mekanisme PTS dalam menunda senesens hampir serupa dengan gas 1-MCP, yaitu mempengaruhi efek fisiologis etilen. Kehadiran PTS secara permanen menggangu penambatan protein reseptor EIN2 yang berperan menginduksi kerja etilen sebagai fitohormon. Dalam kondisi seperti itu, etilen tidak aktif dan jaringan tanaman gagal menampilkan gejala senesen.

Hasil percobaan ini juga mendukung pendapat para ahli fisiologi tumbuhan terdahulu (Arteca, 1996; McGraw, 1995; Salisbury \& Ross, 1995; Taiz \& Zeiger, 1991) bahwa sitokinin mampu menunda senesen pada tingkat sel dan jaringan tanaman. Dalam menunda senesen, sitokinin akan menjaga integritas membran tonoplas untuk mencegah aktivitas enzim yang merombak protein, lipid, khlorofil, dan RNA (Arteca, 1996). Dengan demikian, sitoplasma mampu mengubah beberapa aspek metabolisme seluler antara lain terus menerus menyerap dan menstranslokasikan linarut ke bagian yang membutuhkan (McGraw, 1995) untuk menjaga kesegaran jaringan. Selain itu, penambahan sitokinin eksogen ke dalam jaringan tanaman akan menambah akumulasi sitokinin pada jaringan itu sehingga sintesis etilen dikurangi (Arteca, 1996). Biasanya sitokinin eksogen (khususnya BAP) akan menghambat kerja enzim dalam lintasan etilen, yaitu ACC sintase dan atau ACC oksidase. Bertambahnya umur peragaan anyelir akibat penambahan sitokinin dalam percobaan ini, memperkuat pendapat van Staden et al. (1988) bahwa aplikasi sitokinin dalam larutan pengawet efektif memperpanjang umur peragaan bunga potong anyelir.

Tabel 2. Dinamika bobot segar relatif bunga potong anyelir yang direndam dalam larutan pengawet dengan zat pengatur tumbuh

\begin{tabular}{lccccc}
\hline \multirow{2}{*}{ Perlakuan } & \multicolumn{5}{c}{ Hari ke } \\
\cline { 2 - 5 } & 3 & 5 & 7 & 9 & 11 \\
\hline Formula dasar(Fd) & 89,88 & 77,79 & 65,69 & 53,59 & 41,49 \\
Fd + kinetin 10 mg L-1 & 92,68 & 84,87 & 77,04 & 69,22 & 51,41 \\
Fd + BAP 10 g L L $^{-1}$ & 83,49 & 68,12 & 52,77 & 37,30 & 22,04 \\
Fd + AOA 50 mg L-1 & 86,02 & 70,71 & 55,41 & 40,11 & 24,80 \\
Fd + PTS 50 mg L & 83,86 & 68,15 & 52,44 & 36,71 & 21,02 \\
\hline
\end{tabular}




\section{Bobot Segar Relatif dan Serapan Air Relatif}

Efek perendaman dalam larutan pengawet formula dasar menciptakan pola yang meningkat di awal peragaan, kemudian menurun setelah bunga mencapai mekar maksimum (Tabel 2). Dinamika peningkatan bobot segar relatif di awal peragaan, disebabkan oleh terjadinya pemekaran bunga sehingga bobot segar terus bertambah akibat
Penurunan penyerapan air yang lebih lambat diperlihatkan oleh bunga anyelir terjadi di dalam larutan pengawet formula dasar + kinetin. Penyerapan tersebut adalah $1,48 \mathrm{~g} \mathrm{~g}^{-1}$ pada hari ke tiga dan menurun hingga $0,58 \mathrm{~g} \mathrm{~g}^{-1}$ pada ke 11 . Penurunan serapan air oleh bunga yang direndam dalam formula dasar + AOA tidak proporsional. Pada awalnya serapan air tinggi, tetapi di akhir

Tabel 3. Dinamika serapan air relatif bunga potong anyelir yang direndam dalam larutan pengawet dengan zat pengatur tumbuh

\begin{tabular}{|c|c|c|c|c|c|}
\hline \multirow{2}{*}{ Perlakuan } & \multicolumn{5}{|c|}{ Hari ke } \\
\hline & 3 & 5 & 7 & 9 & 11 \\
\hline & & ---- & $--\mathrm{gg}$ & & -- \\
\hline Formula dasar $(\mathrm{Fd})$ & 0,90 & 0,85 & 0,81 & 0,76 & 0,51 \\
\hline $\mathrm{Fd}+$ kinetin $10 \mathrm{mg} \mathrm{L}^{-1}$ & 1,48 & 1,26 & 1,03 & 0,81 & 0,58 \\
\hline $\mathrm{Fd}+\mathrm{BAP} 10 \mathrm{mg} \mathrm{L}^{-1}$ & 1,48 & 1,42 & 0,97 & 0,78 & 0,51 \\
\hline $\mathrm{Fd}+\mathrm{AOA} 50 \mathrm{mg} \mathrm{L}^{-1}$ & 1,38 & 1,06 & 0,73 & 0,40 & 0,29 \\
\hline $\mathrm{Fd}+\mathrm{PTS} 50 \mathrm{mg} \mathrm{L}^{-1}$ & 0,93 & 0,87 & 0,81 & 0,75 & 0,69 \\
\hline
\end{tabular}

berkembangnya sel-sel petal bunga anyelir itu.

Data pada Tabel 2 menunjukkan bahwa terjadi penurunan bobot segar relatif yang lebih lambat akibat perendaman di dalam larutan pengawet formula dasar dengan kinetin. Hasil percobaan ini memperkuat pendapat Arteca (1996) bahwa sitokinin mampu menunda penuaan sel, jaringan, dan organ tanaman sehingga biomasa organ dapat dipertahankan. Namun, efek perendaman dalam larutan formula dasar + sitokinin (kinetin atau BAP) tidak berbeda dengan formula dasar + PTS, tetapi berbeda dengan formula dasar + AOA atau formula dasar saja. Dengan demikian, mempertahankan bobot segar relatif dapat diken-dalikan oleh hadirnya sitokinin atau PTS.

Efek perendaman dalam larutan pengawet formula dasar terhadap serapan air relatif menunjukkan pola yang semakin menurun dengan bertambahnya umur peragaan (Tabel 3). Penurunan itu disebabkan oleh kondisi alami bahwa sel dan jaringan yang masih muda lebih aktif dalam menyerap air dan linarut yang tersedia di larutan perendam bunga potong itu. Tampaknya kemampuan sel dan jaringan bunga potong sedikit dapat ditingkatkan oleh formula pengawet yang ditambahkan ke dalam air perendam. Serapan air relatif dua harian akibat perbedaan senyawa kimia yang ditambahkan ke dalam larutan pengawet formula dasar tidak berbeda. pengamatan menurun tajam, yaitu dari 1,38 g.g ${ }^{-1}$ pada hari ketiga menjadi $0,29 \mathrm{~g} \mathrm{~g}^{-1}$ pada ke 11 . Diduga saat perendaman di larutan pengawet, bahan aktif media efektif menjaga serapan air tetapi kemudian bunga mengalami cekaman akibat dipindahkan ke dalam dengan $\mathrm{pH}$ lebih tinggi.

Perubahan kemasaman dari asam kuat ke basa secara mendadak menurunkan tekanan osmotik sistem vaskuler sehingga terjadi plasmolisis. Nutrisi yang semula sudah terabsorpsi optimum mengalir meninggalkan sel dan kondisi itu dimanfaatkan oleh mikroba. Akibatnya, serapan air menjadi terhambat. Hasil percobaan ini mendukung pendapat Conrado et al. (1980) bahwa tingkat serapan air oleh bunga potong mawar kultivar Cara Mia berkorelasi erat dengan nilai $\mathrm{pH}$ larutan perendam. Sedangkan menurut Lauchli (1976), air dan linarut diangkut ke atas melalui silem dalam lintasan simplas, dan setiap spesies memiliki struktur silem berbeda mengatasi cekaman.

\section{Sintesis Etilen dan Respirasi}

Efek perendaman dalam larutan formula dasar pada bunga potong anyelir adalah bervariatif terhadap pola jumlah etilen yang disintesis pada hari ke dua, ke empat, ke enam dan ke delapan (Gambar 1). Jumlah etilen yang disintesis terendah diperoleh setelah perendaman dalam larutan formula dasar + PTS, yaitu senilai $1,0 \times 10^{-2} \mu \mathrm{L} \mathrm{g}^{-1} \mathrm{jam}^{-1}$ atau $1 \mu \mathrm{L} \mathrm{kg}^{-1}$ jam $^{-1}$ pada hari ke enam, kemudian diikuti oleh 
formula dasar + kinetin dan formula dasar + AOA. Jumlah etilen yang disintesis oleh bunga anyelir kultivar Red Sims akibat PTS lebih rendah dibandingkan dengan etilen yang disintesis oleh bunga anyelir kultivar White Sims tanpa pengawet, yaitu $40 \mu \mathrm{L} \mathrm{kg}^{-1}$ jam $^{-1}$ dan oleh bunga anyelir kultivar Chinera sebesar $20 \mu \mathrm{L} \mathrm{kg}^{-1}$ jam$^{-1}$ (Wu et al, 1991). Dengan demikian, PTS efektif menekan jumlah etilen yang disintesis oleh bunga anyelir kultivar Red Sims. Hasil yang relatif sama telah dibuktikan oleh Reid et al. (1980), bahwa aplikasi PTS cara pulsing (konsentrasi $1 \mathrm{mM}$ selama 20 jam pada suhu $2{ }^{\circ} \mathrm{C}$ ) pada bunga anyelir tipe spray

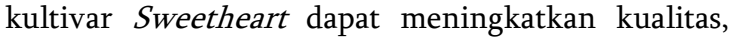
terutama memperpanjang umur peragaan sebesar 43 $\%$ daripada kontrol akibat tertekannya aktivitas etilGG.

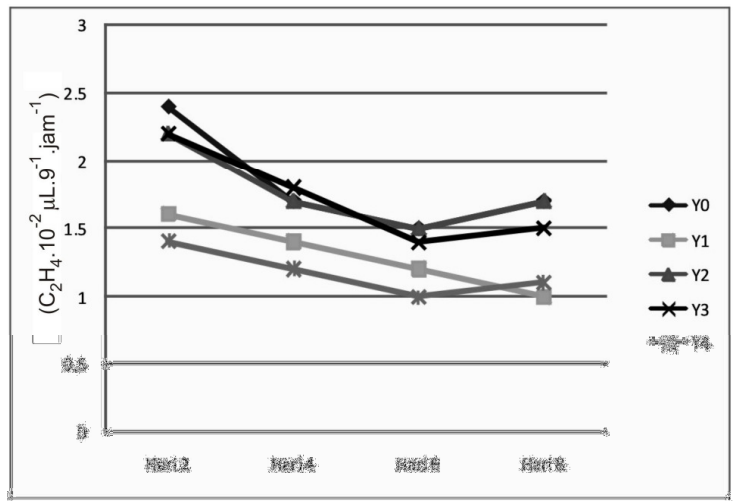

Gambar 1. Jumlah etilen yang disintesis oleh bunga potong anyelir yang direndam dalam formula dasar larutan pengawet (Y0), formula dasar + Kinetin (Y0), formula dasar + BAP (Y2), formula dasar + AOA (Y3) dan formula dasar + PTS (Y4).

Berdasarkan Gambar 1. juga diperoleh informasi bahwa penambahan kinetin ke dalam larutan pengawet formula dasar tampak lebih baik daripada PTS, karena hingga 8 hari kadar etilen masih terus menurun. Tidak terlihat peningkatan etilen seperti pada penambahan bahan lain. Hal itu berarti bahwa kinetin lebih efektif menekan etilen yang disintesis pada bunga potong anyelir kultivar Red Sims. Hasil yang kontras terjadi akibat perendaman dalam larutan pengawet formula dasar + BAP. Dalam percobaan ini seolah-olah BAP tidak mampu mengendalikan jumlah etilen yang disintesis. Namun demikian, data yang diperoleh mendukung hasil percobaan van Meeteren (1979) serta Mayak \& Kofranek (1976), yaitu pengendalian jumlah etilen yang disintesis oleh sitokinin eksogen bergantung pada jenis dan konsentrasi sitokinin serta lokasi dan status bunga potong saat sitokinin itu diaplikasikan. Ditambahkan, bahwa aplikasi beberapa jenis sitokinin melalui cara perendaman tangkai seringkali memberikan sedikit efek penundaan senesen. Hasil yang relatif sama diperoleh Setyadjit et al. (2004) bahwa perendaman bunga potong Greviella kultivar Sylvia dalam larutan yang mengandung 0,1 mM 6benzilaminopurin tidak efektif meningkatkan umur peragaan bunga potong itu.

Berdasarkan nilai $\mathrm{CO}_{2}$ yang terukur pada bunga anyelir kultivar Red Sims (Gambar 2.), dapat disimpulkan bahwa respirasi berpola klimakterik, yaitu terjadi kenaikan jumlah $\mathrm{CO}_{2}$ yang dilepaskan secara lambat pada awal peragaan. Kemudian meningkat pesat (mencapai puncak pada hari keenam hsp), dan turun kembali pada hari kedelapan hsp, yaitu saat hampir mencapai senesens.

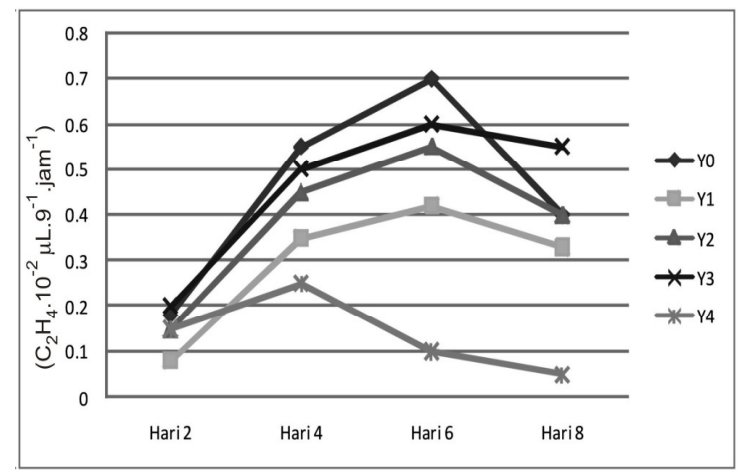

Gambar 2. Respirasi bunga potong anyelir yang direndam dalam formula dasar larutan pengawet (Y0), formula dasar + Kinetin (Y1), formula dasar + BAP (Y2), formula dasar + AOA (Y3) dan formula dasar + PTS (Y4).

Gambar 2. menunjukkan bahwa perendaman larutan pengawet formula dasar + PTS dapat menghambat respirasi bunga anyelir dan mempercepat puncak respirasi yang dicapai pada hari ke empat. Dengan penambahan senyawa lainnya puncak respirasi dicapai pada hari keenam. Jumlah $\mathrm{CO}_{2}$ terendah yang dicapai saat puncak respirasi disebabkan penambahan PTS ke dalam formula dasar, yaitu sebesar $0,04 \times 10^{-2} \mu \mathrm{L} \mathrm{g}^{-1} \mathrm{jam}^{-1}$ atau $4 \mu \mathrm{L} \mathrm{kg}^{-1} \mathrm{jam}^{-1}$ kemudian berturut-turut diikuti oleh penambahan kinetin, BAP, AOA, dan formula dasar. Namun, berdasarkan matriks perbandingan antar kurva, perendaman bunga anyelir dalam larutan pengawet formula dasar + PTS berbeda tidak nyata dengan 
penambahan senyawa kimia lainnya, kecuali jika dibandingkan dengan perendaman dalam larutan pengawet formula dasar saja.

\section{SIMPULAN DAN SARAN}

\section{Simpulan}

Kualitas bunga potong anyelir dapat lebih dipertahankan dengan cara merendamnya di dalam larutan pengawet yang mengandung sukrosa, asam sitrat, dan lisol serta senyawa pengatur tumbuh jenis kinetin atau senyawa anti etilen jenis perak tiosulfat (PTS). Penambahan senyawa kinetin atau PTS ke dalam formula dasar meningkatkan umur peragaan 2 - 3 hari lebih panjang daripada perendaman dalam formula dasar saja. Pada formulasi tersebut jumlah koloni mikroba paling sedikit, bobot segar relatif dipertahankan kesegarannya hingga $85 \%-95 \%$, jumlah etilen yang disintesis terendah, dan kegiatan respirasi dihambat.

\section{Saran}

Mengingat tidak ada perbedaan bermakna antara penambahan kinetin atau PTS ke dalam formula dasar, disarankan untuk memilih senyawa PTS sebagai senyawa tambahan sehingga menjadi formula lengkap bahan pengawet. Saran ini didasarkan atas efisiensi biaya produksi jika bahan pengawet akan dikomersialkan.

\section{UCAPAN TERIMA KASIH}

Terima kasih kepada Prof. H. Husen Djajasukanta, $\mathrm{PhD}$, Prof. H. Ukun Sastraprawira, PhD, dan Dr. Jajang Sauman serta semua pihak yang telah membantu penelitian hingga editing hasil penelitian.

\section{DAFTAR PUSTAKA}

Arteca, RN. 1996. Plant Growth Subtances. Principles and Applications. Chapman and Hall, New York. 332 pp.

Atlas, RM, \& R Bartha. 1995. Microbial Ecology: Fundamentals and Applications. The Benjamin Cummings Publ.Co.,Inc., Menlo Park. 704 pp.

Conrado, LL Shanahan and W Eisinger. 1980. Effects of $\mathrm{pH}$, osmolarity, and oxygen on solution uptake by cut rose flowers. J. Amer. Soc. Hort. Sci. 105: 680 - 683.

Draper, N and H. Smith. 1981. Applied Regression Analysis. $2^{\text {nd }}$ ed. John Wiley and Sons, Singapore. $709 \mathrm{pp}$.
Gaspersz, V. 1991. Teknik analisis dalam penelitian percobaan. Jilid 1. Penerbit Tarsito, Bandung.

Horgan, R. 1995. Hormone analysis: Instrumental methods of plant hormone analysis. p. 415447 In. Plant hormones physiology, biochemistry and molecular biology. P.J. Davies (ed.) Kluwer Academic Publ., Dordrecht, Netherlands.

Iriani, F. 2006. Keefektifan bahan pengawet terhadap peningkatan kualitas bunga potong. Wawasan Tridharma. Majalah Ilmiah Kopertis Wilayah IV. 10:21-24.

Iriani, F. 2009. Formulasi larutan pengawet bunga potong krisan, anyelir, dan herbras. J. Agrikultura. 20:55-61.

Kelly, JW and GL Staby. 1982. Translocation and metabolism of benzyl adenine in cut carnations (Abstract). J. Hort. Science. 17:527.

http://www.springerlink.com/content/t0x43 744147h5359/ (Diakses 13 Oktober 2009).

Kramer, CY. 1972. A First Course in Methods of Multivariate Analysis. Virginia Polytechnic Institute and Univ. Blacksburg, VA. 351 pp.

Lauchli, A. 1976. Symplasmic transport and ion release to the xylem. p. 101-124. In J.B Passioura and I.F Wardlaw (Eds.). Transport and transfer processes in plants. Academic Press, Inc., New York.

Mayak, S and AM Kofranek. 1976. Altering the sensitivity of carnation flowers (Dianthus caryophyllus L.) to ethylene. J. Amer. Soc. Hor. Sci. 101:503-506.

McGraw, BA. 1995. Cytokinin biosynthesis and metabolism. p. 98 -117. In Plant hormones physiology, biochemistry, and molecular biology. P.J. Davies (ed.). Kluwer Academic Publ., Dordrecht.

McKeon, TA, JC Fernandez and SF Yang. 1995. Biosynthesis and metabolism of ethylene. p. 118-213. In Plant hormones physiology, biochemistry, and molecular biology. P.J. Davies (Ed.). Kluwer Academic Publ., Dordrecht, Netherlands.

Reid, MS, DS Farnham and E McEnroe. 1980. Effect of silverthiosulfate and preservatives solutions on the vaselife of miniature carnations. J. Hort. Science. 15: 807-808.

Salisbury, FB and CW Ross. 1995. Fisiologi tumbuhan. Jilid 3. Terjemahan DR Lukman dan Sumaryono. Penerbit ITB Press, Bandung. 
Setyadjit, DC Joice, DE Irving and DH Simons. 2004. Effects of 6-benzylaminopurine treatments ont the longevity of harvested grevillea 'Sylvia' inflorescences. Plant Growth Regulation 43: 9-14.

Sisler, EC and M Serek. 1999. Compounds controlling the ethylene receptor. Bull. Bot. 40: 1-7.

Taiz, L and E Zeiger. 1991. Plant physiology. The Benjamin Cummings Publ. Co., Inc., Redwood City. 559 pp.

Van Meeteren, U. 1979. Water Relations and keeping quality of cut Gerbera flowers. III.
Water content, permeability and dry weight of aging petals. HortScience. 12: 273-281.

Van Staden, J, E Cook and LD Nooden. 1988. Cytokinin and senescence. p. $281-387$ In Senescence and aging in plants. LD Nooden and AC Leopold (Eds.). Acad. Press, IncHarcourt Brace Jovanovich Publ., San Diego.

Wu, MJ, WG van Doorn and MS Reid. 1991. Variation in senescence of carnation (Dianthus caryophyllus L.) cultivars I. Comparison of flower life, respiration and ethylene biosynthesis. Scientia Horticulturae 48: 109-116. 